\title{
Factors delaying spring runoff in the upper Ürümqi River basin, China
}

\author{
RICHARD KATTELMANN \\ Sierra Nevada Aquatic Research Laboratory, Star Route 1, Box 198, Mammoth Lakes, CA 93546, U.S.A. \\ AND YANG DAQING \\ Lanzhou Institute of Glaciology and Geocryology, Academia Sinica, Lanzhou 730000, China
}

\begin{abstract}
Although less than $100 \mathrm{~mm}$ of precipitation generally falls during the winter months in the upper Ürümqi River basin, an uneven snowpack of 20 to $100 \mathrm{~cm}$ depth is present in early spring. When the surface of this snow cover begins to melt in April, the meltwater is not immediately transformed into streamflow. Several processes are responsible for the five to 15 days of delay in streamflow generation: refreezing in the snow cover itself, creation of a basal ice layer at the snow-soil interface, growth of superimposed ice on the glaciers of the basin, ice formation in stream channels and restoration of high albedo by snowstorms that occur about once a week in spring.
\end{abstract}

\section{INTRODUCTION}

Streamflow generated from the melting of seasonal snow cover is a critical source of water for people living downstream of many of the world's mountain ranges. Following the low-flow period of winter, the initial snowmelt runoff of spring is often a vital water resource. Although the timing of the seasonal rise in the snowmelt hydrograph is important for water management operations, physical influences determining the onset of snowmelt runoff have received little scientific attention.

The Ürümqi River of the central section of the Tien Shan provides a good example of the importance of a mountain catchment supplying water to the lowlands. As in much of central Asia and the Himalayan region during winter, solid precipitation and cold temperatures reduce streamflow to a minimum. Snowmelt in April and May provides needed runoff at the start of the growing season before precipitation increases in summer. The headwater area of the Ürüqi River is one of the primary glaciological research sites in central Asia. Most of the work performed in this basin has focused on the summer season when accumulation and ablation are most active (Liu, 1991). The study described here examines processes in the spring when the seasonal snowpack is just beginning to melt. The purpose of this paper is to illustrate the physical controls on initial production of snowmelt runoff in a high-altitude catchment.

\section{STUDY AREA}

The headwaters of the Ürümqi River are on the northern slope of the Kalawucheng region of the central Tien Shan $\left(43^{\circ} 7^{\prime} \mathrm{N}, 86^{\circ} 49^{\prime} \mathrm{E}\right)$. The river flows more than $200 \mathrm{~km}$ northward, supplying water to the city of Ürümqi, capital of the Xinjiang Uygur Autonomous Region. About $1000 \mathrm{~km}^{2}$ of the river basin upstream of Ürümqi is mountainous and generates almost all the streamflow.

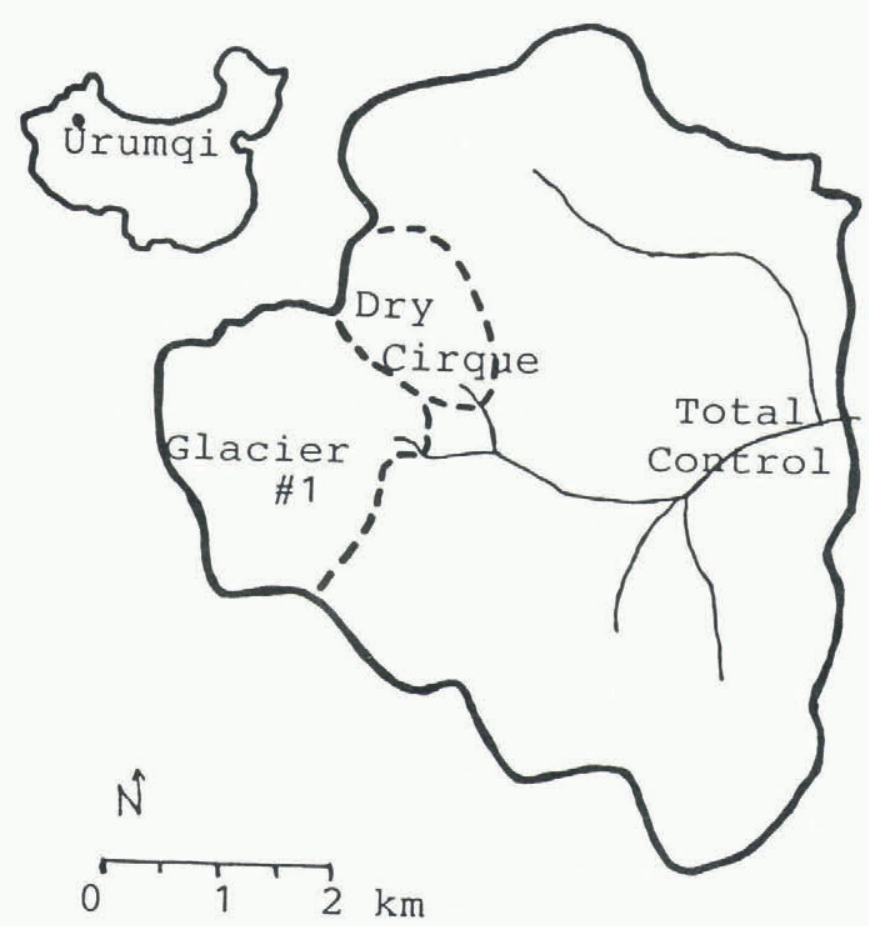

Fig. 1. The primary study areas were located in the upper Ürümqi River basin above the Total Control hydrometric station. 
This area has nearly continuous snow cover above $1650 \mathrm{~m}$ a.s.l. in early March and about half the area is still snowcovered (mainly above $3100 \mathrm{~m}$ ) by early May. Annual water-balance components of the $320 \mathrm{~km}^{2}$ catchment above Leap Forward Bridge at $2400 \mathrm{~m}$, including the study area, were composed of precipitation of $555 \mathrm{~mm}$, evapotranspiration of $275 \mathrm{~mm}$, streamflow of $318 \mathrm{~mm}$ and glacier depletion of $38 \mathrm{~mm}$, averaged from 1984 through 1987 (Zhou and others, 1990).

The primary study area was the $28.9 \mathrm{~km}^{2}$ catchment defined by the Total Control gaging station near the junction of the Daxigou and Luobudao valleys where elevations range from 3300 to $4480 \mathrm{~m}$ (Fig. 1). About a quarter of this basin is covered by seven small glaciers, which have been intensively studied by the Lanzhou Institute of Glaciology and Geocryology since 1959. The sub-basin containing Glacier No. 1 covers $3.34 \mathrm{~km}^{2}$ at elevations from 3700 to $4480 \mathrm{~m}$. The two branches of the glacier cover about $55 \%$ of the gaged catchment. An icefree catchment with predominantly southern exposure known as the Dry (or Empty) Cirque lies adjacent to the Glacier No. 1 basin. A hydrometric station in the Dry Cirque at $3800 \mathrm{~m}$ controls an area of $1.68 \mathrm{~km}^{2}$, which has a maximum elevation of $4300 \mathrm{~m}$.

The continental climate of the Tien Shan results in a mean annual air temperature of $-5^{\circ} \mathrm{C}$ and mean annual precipitation of $560 \mathrm{~mm}$ at the meteorological station in the Total Control basin (Yang and others, 1989). About $70 \%$ of the annual precipitation occurs in June through August. A spatially variable snowpack begins to accumulate in October and begins to melt in April. Runoff from the snowpack initiates streamflow, but summer precipitation and glacier melt account for more than $80 \%$ of the annual streamflow that peaks in July or August.

\section{STREAMFLOW GHARACTERISTICS}

Annual streamflow at the Total Control hydrometric station at the outlet of the $29 \mathrm{~km}^{2}$ basin averaged $450 \mathrm{~mm}$ from 1985 through 1990. The stream channel below Glacier No. 1 is dry from October through April, and more than $90 \%$ of its streamflow occurs from June through August. The average runoff during intermittent gage operation from 1959 to 1983 was about $500 \mathrm{~mm}$ (Li, 1985). From 1984 through 1990, runoff averaged about $580 \mathrm{~mm}$. In contrast, the adjacent Dry Cirque only produced an annual average of $360 \mathrm{~mm}$ of streamflow from 1982 through 1990.

Hydrographs for April through June 1989 provide an example of the seasonal rise in streamflow for the three study basins and the $320 \mathrm{~km}^{2}$ basin gaged at the Leap Forward Bridge downstream (Fig. 2). Streamflow slowly increased downstream at Leap Forward Bridge throughout April from the winter baseflow level, but only a small part of the $320 \mathrm{~km}^{2}$ catchment contributed runoff as shown by the small fraction of a millimeter of equivalent runoff depth at the gage. Streamflow at Leap Forward Bridge did not rise above $1 \mathrm{~mm} \mathrm{~d}^{-1}$ until the streams in the upper basin had begun to flow in early May. In this example year, the beginning of streamflow at the Total Control gage coincided with the first day of measurable
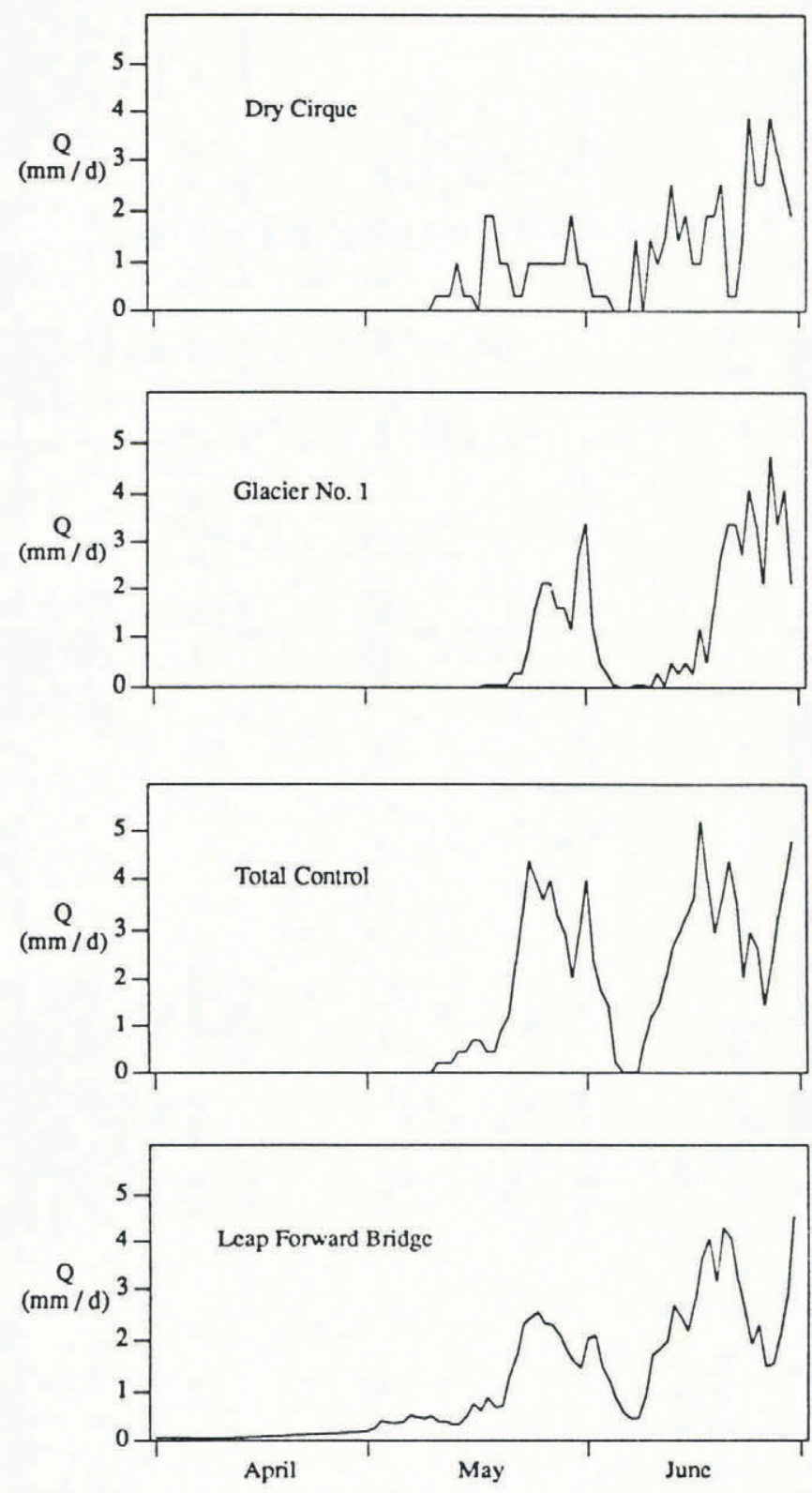

Fig. 2. Hydrographs from four streams in the upper Ürümqi River basin during spring 1989 illustrate differences in the onset of snowmelt runoff.

flow at the Dry Cirque. Most of the initial water at the basin outlet could be expected to be delivered from southfacing slopes which make up much of the Dry Cirque, though we observed runoff from slopes just upstream from the Total Control gage earlier. The first streamflow measured at Glacier No. 1 station lagged the onset of flow at the other upper sites by a full week. Streamflow fell off to zero at all three high-altitude sites in early June following substantial snowfall. A few days later, streamflow at Leap Forward Bridge also fell to a minimum, reflecting the cessation of flow from upstream.

The first day of seasonal streamflow in each year was identified from daily streamflow records from 1984 through 1990. These dates corresponded to the first non-zero value in the record and were usually equivalent to less than $0.5 \mathrm{~mm} \mathrm{~d}^{-1}$ averaged over the basin area. During the period of available record, seasonal streamflow began at the three gaging stations between 20 April 
Table 1. Dates of seasonal onset of streamflow

Year Dry Cirque Glacier No. 1 Total Control

$\begin{array}{rrrr}1984 & 30 \text { April } & \text { late April } & 21 \text { April } \\ 1985 & 3 \text { May } & \text { late April } & \text { late April } \\ 1986 & 10 \text { May } & 12 \text { May } & 7 \text { May } \\ 1987 & 13 \text { May } & 1 \text { June } & 11 \text { May } \\ 1988 & 28 \text { May } & 29 \text { May } & 15 \text { May } \\ 1989 & 11 \text { May } & 18 \text { May } & 11 \text { May } \\ 1990 & 4 \text { May } & 5 \text { May } & 8 \text { May }\end{array}$

and 1 June (Table 1). These dates of streamflow-onset spanned a full month in the two small catchments and three weeks in the entire basin. In most of the years with available data, streamflow was first detected at Total Control, then at Dry Cirque and finally at Glacier No. 1. The onset of streamflow at Glacier No. 1 lagged the onset at Total Control by five to 21 days and at Dry Cirque by one to 19 days. Streamflow often receded to zero for a few days during snowstorms later in May. The remainder of this paper will examine some of the processes controlling the onset of snowmelt runoff and its variability in the upper Ürümqi River.

\section{SEASONAL SNOW GOVER}

The winter snow cover throughout the headwaters of the Ürümqi River tends to be shallow and unevenly distributed. Upper slopes are wind-scoured, and lower slopes may accumulate avalanche debris. Depths can range from zero to a couple of meters, but are usually less than $0.2 \mathrm{~m}$ through March. As precipitation increases in April and May, average snow depths increase to between 0.4 and $0.6 \mathrm{~m}$ (Yang and others, 1991). Snowpack temperatures generally range from -15 to $-20^{\circ} \mathrm{C}$ from January through mid-March and increase to about $-10^{\circ} \mathrm{C}$ in early April and about $-7^{\circ} \mathrm{C}$ in mid-April (Yang and others, 1991). The combination of shallow snow and cold temperatures leads to steep temperature gradients (such as $-0.5^{\circ} \mathrm{C} \mathrm{cm}^{-1}$ ) and well-developed depth hoar. Snow densities in March reach about $300 \mathrm{~kg} \mathrm{~m}^{-3}$, but decrease to about $200 \mathrm{~kg} \mathrm{~m}^{-3}$ in April because fresh snowfall then comprises most of the snowpack (Yang and others, 1991). Densities then increase rapidly as meltwater enters the snowpack. Dust is found at the top of many of the snow layers in the Tien Shan (Tonnessen and others, 1991) and can be expected to decrease the albedo of the snow rapidly when exposed.

In the upper Ürümqi River, snow cover that has accumulated on soil or rock surfaces is generally found on slopes well-exposed to solar radiation, as shaded slopes with northern exposure support the glaciers of the basin. Steep slopes with a southern aspect may rapidly lose snow to sublimation and mid-winter melting. During winter, such meltwater is too limited in volume to generate streamflow and freezes within or below the snow somewhere downslope. The snow cover present after mid-April can melt rapidly at times when the surface energy balance becomes positive. By mid-April, the average snowpack temperature has been warmed by conduction to above $-10^{\circ} \mathrm{C}$ (Yang and others, 1991). Therefore, the cold content of the snow, at depths less than $1 \mathrm{~m}$ and densities less than $350 \mathrm{~kg} \mathrm{~m}^{-3}$, is only 5 to $20 \mathrm{~mm}$ of water equivalence $\left(1700\right.$ to $\left.6700 \mathrm{~kJ} \mathrm{~m}^{-2}\right)$. Capillary retention within and at the base of the snow cover can require a similar amount of water before the snowpack becomes thoroughly wetted. Some loss of water can occur beforehand by movement through isolated channels in areas of convergent flow. In the Dry Cirque, between five and 10 days are required for the entire snowpack to warm to $0^{\circ} \mathrm{C}$, after the surface of the pack first reached the melting point (Yang and others, 1991). Because of the wide variations in snow depths and energy balance within the study area, water may be released from exposed shallow snow several days before deeper deposits receiving less energy contribute to runoff.

In mid-May 1990, we excavated several snow pits in the Dry Cirque. Depths ranged from 0.7 to $1.5 \mathrm{~m}$ and densities ranged from 330 to $380 \mathrm{~kg} \mathrm{~m}^{-3}$. Depth hoar extended from 0 to $0.5 \mathrm{~m}$ from the base of the snowpack. The prominent stratigraphic features of the snow pits were dozens of thin ( 1 to $4 \mathrm{~mm}$ ) discontinuous ice lenses. An extensive ice layer, 20 to $30 \mathrm{~mm}$ thick, was found in two pits. These and other ice features presumably resulted from introduction of meltwater into the formerly cold snowpack (e.g. Marsh and Woo, 1984).

Most of the annual snowfall in the Tien Shan occurs during spring and summer. Where this snow falls on existing snow cover, high albedo is temporarily restored and runoff is delayed. Where snow falls on bare ground, melt is rapid and runoff is enhanced.

\section{FROZEN GROUND}

The substrate also influences the generation of runoff from snowmelt. In a cold environment such as the upper Ürümqi River, the frozen substrate can act as another heat sink and both keep the lower portion of the snowpack colder than it would be otherwise and freeze water at the base of the snowpack (Marsh and Woo, 1984; Marsh, 1987). Percolating meltwater can freeze into a basal ice layer until the near-surface layers of the ground have been warmed to $0^{\circ} \mathrm{C}$ by the release of latent heat. Basal ice was found in most pits and was between 100 and $150 \mathrm{~mm}$ thick in one pit. The presence and thickness of basal ice layers found in snow pits in the Dry Cirque probably relate to intensity of soil cooling as affected by topography and local thickness of snow cover over the course of the winter (Yang, 1990). After basal ice formation stops, water will flow downslope in a saturated layer over the impermeable ice and/or saturated ground. There is little interchange of surface and subsurface water during these conditions (Price and others, 1979; Yang, 1990), and runoff can occur within a matter of hours once depression storage is filled (FitzGibbon and Dunne, 1981).

During May 1990, we found that most areas of bare 
ground in the catchment were saturated close to the surface, with the exception of zones of strongly divergent flow such as drainage divides. Also, terrain depressions a few centimeters deep were holding a substantial amount (tens of millimeters) of water. Low vegetation around these depressions enhanced their storage. Most areas of convergent topography were saturated and draining downslope. Snowfall in May 1990 on to the bare, wet ground melted soon after deposition and became runoff, once storage in the microrelief was satisfied. In the Tien Shan, frozen soil can act both as a delaying factor to runoff because of its cold content and as a runoffenhancing factor because of the low permeability of the basal ice and ground surface.

\section{SNOW ON GLACIERS}

By mid-April, the snowpack on the glaciers of the basin above the Total Control gage tends to be deeper than snowpacks of the Dry Cirque and other south-facing slopes. Clearly, the glaciers occupy locations where snow accumulation is greater and energy input is less than in the ice-free portions of the basin. Although snow temperatures over ground and glacier have been similar to each other in January and February, snow on Glacier No. 1 has been from 2 to $4^{\circ} \mathrm{C}$ cooler at its base and from 1 to $2^{\circ} \mathrm{C}$ cooler at its surface than snow in the Dry Cirque (Yang and others, 1991). By the beginning of May, these temperature differences have been as large as 8.5 and $4.5^{\circ} \mathrm{C}$, respectively, because less energy was available to snow on the glaciers, and temperatures of the ice were colder than those of the ground (Yang and others, 1991).

Snow on Glacier No. 1 has been observed to start melting seven to 10 days later than snow on either the ground in the Dry Cirque or in the south-facing portion of the basin containing Glacier No. 1. These south-facing slopes may be expected to contribute all the water to initial streamflow from the Glacier No. 1 catchment. By 15 May 1990, streams located between the base of the south-facing slope and the northern margin of ice in each branch of the glacier were carrying substantial (tens of liters per second) flows. On the lower portion of the glacier, water was flowing in channels on the ice, under the winter snowpack. Streamflow was first recorded at the hydrometric station 10 days earlier.

Snow on the central portion of each branch of Glacier No. 1 reached the melting point, except near the base, by the middle of May 1990. However, on steep slopes with northern exposure, the snow was still -4 to $-6^{\circ} \mathrm{C}$ and 1 to $4 \mathrm{~m}$ deep. A melt-freeze crust on the surface, and ice columns and thin ice lenses in the top $0.5 \mathrm{~m}$, suggested that although meltwater was being generated at the surface, an insufficient amount had been produced to warm the snow cover to $0^{\circ} \mathrm{C}$ by release of latent heat of refreezing. Such slopes do not contribute water to runoff during the first weeks of seasonal streamflow.

After the thermal and capillary storages of the snowpack have been filled, the underlying firn and ice also reduce the potential runoff. In the Alaska Range of North America, internal accumulation alone can delay release of water for two to four weeks at an average melt rate of $10 \mathrm{~mm} \mathrm{~d}^{-1}$ (Trabant and Mayo, 1985). On the central and upper portions of Glacier No. 1 during May, near-surface ice temperatures are generally between -10 and $-15^{\circ} \mathrm{C}$ depending on thickness of the winter snowpack. Such temperatures have the potential to refreeze 50 to $200 \mathrm{~mm}$ of water equivalence (e.g. Trabant and Mayo, 1985; Röthlisberger and Lang, 1987), or about an order of magnitude more than the cold content of the overlying snowpack. However, the amount of refreezing could be only about half of the potential quantity depending on the degree of warming of the ice by conduction and disposition of latent heat strength (Ambach, 1961; Calanca and Heuberger, 1990).

Refreezing of meltwater by the cold content of the firn and ice can take several forms: ice lenses and columns within the snowpack, superimposed ice at the snowpack/ firn interface and internal accumulation within the old firn and ice (Xie and others, 1965; Bazhev, 1973). Superimposed ice is the primary type of refrozen ice found on Glacier No. 1 (Xie and Zhang, 1989). In midMay 1990, we found 0.2 to $0.3 \mathrm{~m}$ of superimposed ice over the previous year's firn in pits in the center of Glacier No. 1. Temperatures of this ice were still -4 or $-5^{\circ} \mathrm{C}$, suggesting that most of it was formed the previous autumn, which is when the potential for ice formation from capillary storage is greatest (Trabant and Mayo, 1985; Bazhev, 1989). Most of the superimposed ice formed in spring on Glacier No. 1 is found on the lowest third of the glacier where slopes are low, the insulating snow cover is relatively thin and water is supplied from upslope through lateral downslope flow of water through the snowpack (Cai and others, 1986; Cai and Wang, 1989). After a layer of impermeable superimposed ice has formed, subsequent percolating water had been observed to flow over the new ice, leaving underlying firn layers unsaturated. Major variations in temperature and ice thickness over short distances have been found in Alpine glaciers and attributed to spatial variations in movement of water (Hughes and Seligman, 1939). Convergence of water into the supraglacial channels on Glacier No. 1 also reduces the opportunity for water to refreeze.

\section{GHANNEL STORAGE}

When meltwater reaches a stream channel, there is a final source of delay. Initially, the channels are clogged with snow because of snow drifting into terrain depressions, as has been described for the Arctic (e.g. Woo and Sauriol, 1981). Water also freezes in channels, removing that water from runoff and forcing subsequent flow out of the channel where additional freezing can take place. In May 1990 , we found stream ice deposits up to $2 \mathrm{~m}$ thick and extensive ice in a meadow where water spreads out of the channel above the Dry Cirque hydrometric station. This combination of processes can prevent the small quantities of initial snowmelt runoff from flowing downstream, thereby adding a couple of days of delay to the lags caused by the snowpack and substrate.

\section{SUMMARY}

In the Ürümqi River basin, snowmelt runoff in spring 
provides the first relief from the winter minimum in streamflow. Spring streamflow in the headwaters of the Unrümqi River generally begins sometime between late April and late May. The timing of this initial rise in streamflow depends on the energy balance of the snow surface and on a variety of processes that control the release of meltwater to streams. The cold content and capillary storage of the snowpack retain a few millimeters of water in the shallow and low-density snow cover. Several tens of millimeters of meltwater can be refrozen at the base of the snow cover because of the cold content of the underlying ground or glacier. Additional water forms a saturated layer at the base of the snow and fills depressions in the microtopography of the substrate before much water can approach stream channels. Even in the main channels, clogging by snow and ice formation can cause additional delays to the release of water from the catchment. Because of these various delays, substantial streamflow may not begin for one to two weeks after the start of snowmelt. The amount of delay imposed by these different factors varies with terrain properties and snow depth. The spatial distribution of source areas affected by these factors needs to be considered along with the spatially variable energy balance to improve understanding and prediction of initial snowmelt runoff.

\section{ACKNOWLEDGEMENTS}

J. Dozier, J. Frew, J. Melack, J. Shi and Z. Wan provided logistical help in the U.S.A. Y. Shi, Z. Xie, the staff of the Lanzhou Institute of Glaciology and Geocryology and the Institute for Remote Sensing Applications in Beijing provided logistical help in China. A. Chichagov, K. Elder, K. Tonnessen, S. Ushnurtsev, M. Williams and the staff of the Tien Shan Glaciological Station provided critical help in the field.

\section{REFERENCES}

Ambach, W. 1961. Die Bedeutung des aufgefrorenen Eises (superimposed ice) für den Massen- und Energiehaushalt eines Gletschers. Z. Gletscherkd. Glazialgeol., 4(3), 169-189.

Bazhev, A. B. 1973. Infiltration and run-off of melt water on glaciers. International Association of Scientific Hydrology Publication 93 (Symposium at Reading 1970 - World Water Balance, Vol. 2), 245-250.

Bazhev, A.B. 1989. Osobennosti l'doobrazovaniya na teplykh lednikakh [Peculiarities of ice formation on temperate glaciers]. Materialy Glyatsiologicheskikh Issledovaniy 67, 153-162.

Cai Baolin and Wang Liangwei. 1989. The research of snow temperature and melt-water percolation in the infiltration of a glacier. F. Glaciol. Geocryol., 11(1), 6068. [In Chinese with English abstract.]

Cai Baolin, Xie Zhichu and Huang Maohuan. 1986. Mathematical models of the temperature and waterheat transfer in the percolation zone of a glacier. Cold Reg. Sci. Technol., 12(1), 39-49.

Calanca, P. and R. Heuberger. 1990. Energy balance. Zürcher Geogr. Schr. 38, 60-75.
FitzGibbon, J.E. and T. Dunne. 1981. Land surface and lake storage during snowmelt runoff in a subarctic drainage system. Arct. Alp. Res., 13(3), 277-285.

Hughes, T.P. and G. Seligman. 1939. The temperature, melt water movement and density increase in the neve of an Alpine glacier. Mon. Not. R. Astron. Soc. Geophysical Supplement, 4(8), 616-647.

Li Nianjie. 1985. Characteristics of runoff in the Glacier No. 1 region at headwater of Urümqi River, Tien Shan. 7. Glaciol. Geocryol., 7(2), 170-179. [In Chinese with English abstract.]

Liu, C., comp. 1991. Handbook of Tien Shan Glaciological Station. Lanzhou, Gansu Science and Technology Press.

Marsh, P. 1987. Factors limiting snowmelt runoff in a permafrost environment. Proc. IVest. Snow Conf. 55th Annual Meeting, 61-68.

Marsh, P. and M. Woo. 1984. Wetting front advance and freezing of meltwater within a snow cover. 1 . Observations in the Canadian Arctic. Water Resour. Res., 20(12), 1853-1864.

Price, A. G., L. K. Hendrie and T. Dunne. 1979. Controls on the production of snowmelt runoff. In Colbeck, S. C. and M. Ray, eds. Modeling of snow cover runoff. Hanover, NH, U.S. Army Corps of Engineers. Cold Regions Research and Engineering Laboratory, 257-268.

Röthlisberger, H. and H. Lang. 1987. Glacial hydrology. In Gurnell, A. M. and M.J. Clark, eds. Glacio-fluvial sediment transfer; an alpine perspective. Chichester, etc., John IViley and Sons, 280-284.

Tonnessen, K., K. Elder, R. Kattelmann and M. Williams. 1991. Seasonal snowpack dynamics and chemistry in the Sierra Nevada (California, USA) and the Tien Shan (Xinjiang Province, China). Proc. West. Snow Conf. 59th Annual Meeting, 146-149.

Trabant, D. C. and L.R. Mayo. 1985. Estimation and effects of internal accumulation on five glaciers in Alaska. Ann. Glaciol., 6, 113-117.

Woo, M. and J. Sauriol. 1981. Effects of snow jams on fluvial activities in the high Arctic. Physical Geography, 2(1), 83-98.

Xie Zichu and Zhang Wenjing. 1989. Characteristics of ice formation in the west Kunlun mountains. Bull. Glacier Res. 7, 29-35.

Xie Zichu, M. Wang and L. Mei. 1965. The structure of ice and firn on Glacier No. 1 at the head of the Ürümqi River. In Upper Ürümqi River. Lanzhou, Lanzhou Institute of Glaciology and Geocryology, 1-13. [In Chinese.]

Yang Daqing, Shi Yafeng, Kang Eris and Zhang Yinsheng. 1989. Research on analysis and correction of systematic errors in precipitation measurements in Wulumqi River basin, Tien Shan. In Sevruk, B., ed. Precipitation measurements. WMO|IAHS/ETH Workshop... St Moritz, 3-7 December 1989, 173-179.

Yang Daqing, Zhang Yingsheng, Zhang Zhizhong, K. Elder and R. Kattelmann. 1991. Physical properties of snow cover and estimation of snowmelt runoff in a small watershed in high alpine Tien Shan. International Association of Hydrological Sciences Publication 205 (Symposium at Vienna 1991 - Snow, Hydrology and Forests in High Alpine Areas), 169-177.

Yang, Z. H. 1990. The formation and calculation of cold 
region runoff in the Qilian mountains. International Association of Hydrological Sciences Publication 193. (Symposium at Lausanne $1990-$ Hydrology in Mountainous Regions. I. Hydrological Measurements; the Water Cycle), 677-684.

Zhou, Y., G. Zhang and E. Kang. 1990. Water balance analysis and water resources in the mountain area of Ürümqi River basin. Ingénieurs et Architectes Suisses, 18, 365-267.

The accuracy of references in the text and in this list is the responsibility of the author/s, to whom queries should be addressed. 